\title{
Pola Pengelolaan Good Corporate Governance Badan Layanan Umum
}

\section{Good Corporate Governance Management Patterns Public Service Agency}

\author{
Amira Nurlatifa ${ }^{* 1}$, Bambang Suratman dan Hariyati \\ Pendidikan Ekonomi Pascasarjana Universitas Negeri Surabaya, Indonesia
}

The purpose of this study was to determine the meaning of good corporate governance, the application of the management patterns of good corporate governance in universities and the obstacles faced by good corporate governance in universities. This research is a qualitative research which is literature study. The results of the study reveal that good corporate governance has the meaning of a good governance system, especially important in universities based on the principles of good governance in universities, such as the principle of accountability which is manifested in positive and negative independence without pressure from any party, as well as the principle of equality and fairness to stakeholders. Apart from this, there are internal problems, one of which is due to the inadequate duties and functions of

OPEN ACCESS

ISSN 2548-3501 (online)

Edited by:

Eny Maryanti

Reviewedby:

Supriyati.

${ }^{*}$ Correspondence:

Amira Nurlatifa amira.18004@mhs.unesa.ac.id

Received: 29 April 2020

Accepted: 10 January 2021

Published: 31 January 2021

Citation:

Nurlatifah, Suratman dan Hariyati (2021) Pola Pengelolaan Good Corporate Governance Badan Layanan Umum special institutions dealing with development. Meanwhile, external problems occur due to the rapid development of science and technology that does not yet fulfill sufficient capacity to implement good governance in the management of education in Indonesia

Keywords: Good Corporate Governance, Public Srvice Agency, Higher Education

Tujuan dari penelitian ini adalah untuk mengetahui pengertian dari good coorporate governance, penerapan pola pengelolaan good coorporate governance pada perguruan tinggi serta hambatan-hambatan yang dihadapi good coorporate governance pada perguruan tinggi. Penelitian ini adalah penelitian kualitatif yang bersifat studi pustaka. Hasil penelitian mengungkapkan bahwa good coorporate governance memiliki makna sistem tata kelola yang baik khususnya penting dalam universitas berlandaskan prinsipprinsip Good Governance di PT seperti prinsip akuntabilitas diwujudkan kompensasi positif dan negatif, prinsip transparansi dengan pelaksanaan audit eksternal, prinsip pertanggungjawaban dengan terwujudnya Dewan Pengawas, prinsip kemandirian tanpa tekanan dari pihak manapun, serta prinsip kesetaraan dan kewajaran terhadap stakeholders. Selain hal tersebut terdapat permasalahan internal salah satunya disebabkan belum optimalnya tugas dan fungsi lembaga khusus menangani pengembangan. Sedangkan permasalahan eksternal terjadi karena adanya perkembangan ilmu dan teknologi yang demikian pesat belum memenuhi kapasitas yang memadai untuk dapat terselenggaranya good governance dalam pengelolaan pendidikan di Indonesia. 


\section{PENDAHULUAN}

Pendidikan merupakan satu sektor yang sangat penting, yang akan selalu mengalami pembaharuan, menyesuaikan, dan mengikuti perkembangan zaman. Peraturan yang mengatur pendidikan tinggi adalah Undang-Undang No.12 Tahun 2012 yang merupakan dasar legal, pengaturan dan tatakelola penyelenggaraan seluruh pendidikan tinggi (PT) di Indonesia yang memberikan otonomi sepenuhnya kepada perguruan tinggi. Perguruan tinggi memerlukan pengelolaan yang baik demi kepentingan masyarakat luas terutama bertujuan mencerdaskan kehidupan bangsa. Konsep pengelolaan yang saat ini sedang digalakkan terutama dalam penyelenggaraan perusahaan public adalah konsep Good Coorporate Governancee atau GCG. Pada universitas/perguruan tinggi konsep pengelolaan koorporasi yang solid yang diterapkan adalah Good University Governance atau GUG (Hambani, 2015).

University Governance (UG) merupakan salah satu elemen penting dari reformasi di perguruan tinggi, yang sering disebut Good University Governance (GUG) untuk "best practices"-nya serta dinilai sebagai elemen penting bagi perguruan tinggi agar dapat mengantisipasi, mendesain, melaksanakan, memantau, dan menilai efisiensi dan efektivitas kebijakan (Henard dan Mitterle, 2010). Akomodir internasiolisasi PT adalah tujuan dari GUG, peningkatan daya saing, peningkatan kualitas manajemen internal, peningkatan kualitas proses pembelajaran, dan agar tercapainya kinerja yang diharapkan (Henard dan Mitterle, 2010; Salmi, 2009).

Muchlis (2012) Dunia pendidikan menduduki situasi yang penting hal ini disebabkan oleh adanya globalisasi dan tuntutan transparan serta keterbukaan, mengakibatkan kepedulian terhadap praktik pendidikan dan pengembangan strategi dari pemerintah yang menjadikan pendidikan sebagai kerangka penting dalam pembangunan ekonomi. Hai ini bertujuan guna menanggapi berkembangnya persaingan di pasar pendidikan, pengembangan tuntutan guna privatisasi di dunia pendidikan, meningkatkan individualisme kompetitif dalam praktik pendidikan serta pengembangan strategi untuk menjadikan pendidikan dalam pengembangan ekonomi lokomotif.

Selanjutnya, inti dari suatu industri adalah pendidikan (berdasarkan tinjauan ekonomi tentang pendidikan). Tinjauan ini menghasilkan tuntutan pada dunia pendidikan untuk membuat tata kelola universitas yang baik berdasarkan penerapan pada dunia bisnis. Namun dalam penerapannya dibutuhkan kehati-hatian karena dunia bisnis dan dunia pendidikan mempunyai perbedaan yang mendasar berdasarkan filosofi masing-masing (Rhini Fatmasari, 2017).

University Governance (UG) merupakan salah satu elemen penting dari reformasi di perguruan tinggi, yangsering disebut Good University Governance (GUG) untuk "best practices"-nya serta dnilai sebagai elemen penting bagi perguruan tinggi agar dapat mengantisipasi, mendesain, melaksanakan, memantau, dan menilai efisiensi dan efektivitas kebijakan (Henard dan Mitterle, 2010). Akomodir internasiolisasi PT adalah tujuan dari GUG, peningkatan daya saing, peningkatan kualitas manajemen internal, peningkatan kualitas proses pembelajaran, dan agar tercapainya kinerja yang diharapkan (Henard dan Mitterle, 2010; Salmi, 2009).

Penerapan tata kelola keuangan di universitas sementara masih sangat bervariasi. Keberhasilan implementasi sistem manajemen termasuk tata kelola keuangan dipengaruhi oleh banyak pihak serta dapat digolongkan menjadi dua faktor, yaitu faktor internal dan faktor eksternal. "Untuk mewujudkan tata kelola universitas yang baik, universitas diharapkan melakukan berbagai upaya guna meningkatkan transparansi serta akuntabilitas umum, banyak faktor yang memengaruhi: budaya organisasi, kompetensi manajemen, komitmen organisasi, kepemimpinan, efektivitas audit internal, dan penerapan sistem akuntansi"(Januri, 2015).

Sudah saatnya perguruan tinggi menerapkan good corporate governance dalam pengelolaan penyelenggaraan pendidikan. Karena organisasi PTN berbeda dengan organisasi Bisnis pada umumnya, maka implementasi GCG di PTN lebih tepat disebut dengan good university governance. GUG merupakan sebuah konsep yang muncul karena kesadaran bahwa penyelenggaraan perguruan tinggi dan institusi perguruan tinggi memang tidak dapat disamakan dengan penyelenggaraan sebuah negara atau korporasi. Berdasarkan penjelasan diatas, maka tujuan penelitian ini adalah untuk mengetahui pola pengelolaan Good Coorporate Governance pada Perguruan Tinggi dan Hambatan-hambatan apa saja yang dihadapi Good Coorporate Governance pada Perguruan Tinggi.

\section{METODE}

Penelitian ini adalah penelitian kualitatif yang bersifat studi pustaka (library research) yang menggunkan buku-buku dan literatur-literatur lainnya sebagai objek yang utama (Hadi, 1995). Jenis penelitian yang digunakan adalah kualitatif, yaitu penelitian yang menghasilkan informasi berupa catatan dan data deskriptif yang terdapat di dalam teks yang diteliti (Mantra, 2008: 30). Dengan penelitian kualitatif, perlu dilakukan analisis deskriptif. Metode analisis deskriptif memberikan gambaran dan keterangan yang secara jelas, objektif, sistematis, analitis dan kritis mengenai pola pengelolaan keuangan pada badan layanan umum yang berhubungan dengan good university governance yang terdiri dari 5 prinsip yaitu accountability, transparency, responsibility, independency, serta fairness terhadap pola pengelolaan keuangan badan layanan umum yang didasarkan pada Manual Pengelolaan Satker BLU Bidang Layanan Pendidikan (2013) serta Undang-Undang Republik Indonesia Nomor 1 Tahun 2004 Tentang Perbendaharaan Negara. Pendekatan kualitatif yang didasarkan pada langkah awal yang ditempuh dengan mengumpulkan data-data yang dibutuhkan, kemudian dilakukan klasifikasi dan deskripsi. 


\section{HASIL DAN PEMBAHASAN}

Dengan adanya pola BLU yang diterapkan oleh setiap instansi pemerintah yang secara fungsional dalam penyelenggaraan kegiatan yang mempunyai sifat operasional. Instansi tersebut dapat berasal dari dan menduduki pada berbagai jenjang eselon atau non eselon. Berdasarkan hal tersbut, diperlukan penyesuaian dengan melihat ketentuan peraturan pemerintah dan peraturan pelaksanaan bagi organisasi dan struktur instansi pemerintah yang hendak menerapkan PPK-BLU.

\section{Good Corporate Governance}

Governance terdiri dari berbagai jenis organisasi, publik atau privat, non-profit atau for-profit, sektor dan industri yang disesuaikan pada karakteristik masing-masing organisasi (Quyen, 2014). Pengaturan secara mandiri oleh universitas melalui bentuk dan proses kostitusional disebut sebagai University governance (Shattock, 2006). Governance of Irish Universities (2007) menjelaskan GUG sebagai berikut:

"A robust system of governance is vital in order to enable organizations to operate effectively and to discharge their responsibilities as regards transparency and accountability to those they serve. Given their pivotal role in society and in national economic and social development, as well as their heavy reliance on public as well as private funding, good governance is particularly important in the case of the universities".

Governance menekankan pada pelaksanaan fungsi governing secara bersama-sama oleh pemerintah dan institusi institusi lain, yaitu LSM, perusahaan swasta maupun warga negara. Bahkan institusi non pemerintah ini dapat saja memegang peran dominan dalam governance tersebut, atau bahkan lebih dari itu pemerintah tidak mengambil peran apapun "governance without government" (Wibawa, 2006). "Implementasi GUG diperguruan tinggi adalah dalam rangka pengelolaan intitusi yang- solid dengan tetap menjungjung tinggi cita-cita bangsa dalam mencerdaskan warga negara dan meningkatkan nilai dan kualitas institusi. Sejalan dengan hal tersebut, terdapat dasar fungsi dan peran Tri Dharma PT adalah kewajiban Perguruan Tinggi untuk menyelenggarakan Pendidikan, penelitian, dan pengabdian kepada masyarakat" (UU No. 12 Tahun 2012, Pasal 1 Ayat 9) itulah maka pengelolaan sebuah institusi PT berbeda dengan pengelolaan korporasi maupun sebuah negara. Terdapat beberapa koridor tertentu yang dikaitkan dengan nilai-nilai luhur (values), baik dalam hal akademik maupun social values yang wajib dijaga didalamnya. Beberapa hal lainnya dalam proses menyelenggarakan PT harus digunakan sebagai alat sebagai pendukung tercapainya tujuan dasar tersebut (Anwar dan Pratolo, 2012).
Maka, berdasarkan penjelasan di atas dapat disimpulkan bahwa good governance memiliki makna sistem tata kelola yang kuat sangat penting untuk memungkinkan lembaga atau organisasi diwujudkan dengan usaha dan semangat kerja oleh semua pihak, yang ditandai dengan adanya prinsip transparansi, akuntabilitas, partisipasi, efisiîensi dan efekktivitas sistem pengelolaanya. Mengingat peran suatu lembaga atau oragnisasi tersebut mereka yang sangat penting dalam masyarakat dan dalam pembangunan ekonomi dan sosial nasional, serta ketergantungan mereka yang besar pada pendanaan publik dan swasta, tata kelola pemerintahan yang baik khususnya penting dalam universitas yang sejalan dengan UU No. 12 Tahun 2012 serta fungsi dan peran Tri Dharma PT merupakan kewajiban Perguruan Tinggi untuk menyelenggarakan Pendidikan, penelitian, dan pengabdian kepada masyarakat.

Agar semua apa yang diperlukan oleh manajemen perguruan tinggi dan mengendalikan anggran maka ditetapkan unit utama sebagai pihak yang menanggung jawab program atau annggaran yang terdiri dari tig ahal penting yaitu (1) proses proses perencanaan dan penganggaran; (2) proses pelaksanaan anggaran; serta (3) proses pelaporan dan pertanggungjawaban

Pada tahap pertama yaitu Penyusunan Rencana Bisnis dan Anggaran (RBU) BLU dilaksnakan melalui ketentuan sebagai berikut: (1) Penyusunan rencana strategis bisnis lima tahunan yang mengacu pada rencana strategis kementerian negara/lembaga; (2) Penyusunan RBA tahunan yang berpatokan pada rencana strategis bisnis; (3) Penyusunan RBA didasarkan pada basis kinerja; (4) Menghitung akuntansi biaya melalui standar biaya yang ditentukan oleh pemimpin BLU; (5) Setidaknya disajikan perhitungan biaya langsung dan biaya tidak langsung; (6) Pada bagian hal belum tersusunnya standar biaya oleh BLU, BLU memakai standar biaya yang ditentukan oleh Menteri Keuangan/gubernur/bupati/walikota sesuai dengan wewenang masing-masing.

Selanjutnya pada tahap kedua yaitu Pelaksanaan Anggaran BLU terdiri dari: (1) pendapatan pada BLU dilaksanakan dengan ketentuan penerimaan anggaran yang bersumber dari APBN/APBD diberlakukan sebagai pendapatan BLU; (2) pengelolaan kas pada BLU dilaksanakan melalaui praktek bisnis sehat sesuai dengan ketentuan peraturan perundang-undangan; (3) pengelolaan piutang BLU diselenggarakan melalui penyerahan barang, jasa; (4) pengelolaan utang BLU pengelolaan dan penyelesaiannya dilakukan dengan tertib.

Tahap terakhir yaitu Pelaporan dan Pertanggungjawaban Keuangan BLU dilakukan dengan ketentuan sebagai berikut: (1) setiap terjadi transaksi keuangan pada BLU wajib diakuntansikan dan dilampirkan bukti/dokumen pendukungnya serta pengelolaan dilakukan dengan tertib; (2) akuntansi dan pelaporan keuangan BLU dilaksanakan dengan Standar Akuntansi Keuangan yang sesuai terbitan oleh asosiasi profesi akuntansi Indonesia; (3) tidak adanya standar akuntansi, BLU bisa melakukan penerapan 
standar akuntansi industri yang spesifik sesudah disetujui oleh Menteri Keuangan; (4) dikembangkan dan diterapkannya sistem akuntansi oleh BLU yang dengan pokok standar akuntansi yang diberlakukan sesuai jenis pelayanannya dan penetapan oleh menteri atau pimpinan lembaga.

Good University Governance tidak hanya memiliki sifat tunggal terhadap prerogatif administratif saja, namun juga bersifat terhadap responsibilitas dan upaya bersama, dimana partisipasi dilibatkan dalam keseluruhan komponen konstituen universitas. Seperti halnya pendapat Soaib (2009) bahwa dalam menerapkan prinsip-prinsip dasar konsep "good governance" pada institusi perguruan tinggi dapat menggunakan good university governance. Penerapan prinsipprinsip dilakukan melalui beberapa penyesuaian berdasarkan nilai-nilai yang wajib dijunjung tinggi dalam pelaksanaan khususnya perguruan tinggi dan pendidikan secara umum melalui basis pada tujuan mengembangkan pendidikan dan keilmuan akademik serta mengembangkan manusia secara utuh. Berdasarkan hal diatas memunculkan Tri Dharma Perguruan Tinggi melalui nilai-nilai yang menjadi sasarnya, dianatara lain adalah:

\section{Accountability}

Meyer (2010) menyatakan dalam konsep fenomologi mengenai institutional theorynya bahwa terbentuknya institusi sebabkan oleh kompleksitas dan keberagaman peran, fungsi dan heterogenitas unsur yang disatukan di dalam sebuah wadah, yang dinamakan institusi. Ferry (2010) penerapan akuntabilitas antara lain meliputi: “(1) kompensasi positif adalah penghargaan yang diberikan kepada setiap pegawai, misalkan saja para pegawai dan dosen yang aktif menulis buku terdapat penghargaan untuk menulis buku, kemudian bagi para dosen yang aktif ke luar negeri akan diberikan fasilitas biaya transportasi dan lain-lain: (2) kompensasi negatif yang dimaksud adalah penjatuhan sanksi atau hukuman terhadap pelanggaran yang dilakukan oleh pegawai di lingkungan. Pelanggaran tersebut mulai dari pelanggaran ringan, pelanggaran sedang hingga pelanggaran berat.”

\section{Transparancy}

Penyedia dan keterbukaan informasi bagi stakeholders merupakan tanggung jawab yang harus dilakukan oleh Universitas sehingga posisi dan pengelolaan korporasi (perguruan tinggi) dapat dicerminkan sebagai kondisi riil dan harapan terhadap perguruan tinggi di masa mendatang, serta kebutuhan akan pemeliharaan legitimasi organisasi. Bagaimana mekanisme yang dilalui organisasi berusaha menyelaraskan praktik dan karakteristiknya dengan nilai-nilai sosial dan budaya menjadi terlembaga dalam organisasi khusus. Ferry (2010) penilaian terhadap penerapan transparansi, antara lain meliputi:" (1) pertanggungjawaban atas akuntabilitas kinerja dan kegiatan yang digunakan sebagai salah satu dokumen penting dalam siklus perencanaan, pemantauan dan umpan balik untuk tahun berikutnya sebagai bentuk transparansi kepada public; (2) transparansi atas UKT bertujuan untuk mempermudah akses pendidikan tinggi bagi seluruh masyarakat; (3) pelaksanaan audit eksternal dilakukan dalam rangka mewujudkan transparansi atas semua aspek yang berhubungan dengan penyediaan dan penyampaian informasi keuangan agar dapat terpeliharanya kepercayaan dari masyarakat."

\section{Responsiveness}

Suatu tempat bagi individu secara continue melakukan pencarian cara penciptaan realitas dan ialah proses selalu ada dan tanpa henti dan berkesinambungan dinamakan organisasi pembelajaran. Dalam institutional theory, March dan Olsen (dalam Peters, 2000) berpendapat "institusi dapat bersifat adaptive bila interaksi, struktur dan perubahan pada sistem lingkungan menjadi lebih kompleks. Universitas merespons dinamika university governance berdasarkan prinsip kepedulian responsiveness yang membuat Universitas sebagai institusi yang dapat menjadi jawaban kebutuhan dan pengembangan dan pertumbuhan knowledge"

Sedangkan Ferry (2010) penerapan responsibilitas antara lain meliputi: "(1) dilaksanakannya program kemitraan daerah, dimana program ini adalah salah satu program seleksi masuk PT dengan ketentuan calon mahasiswa dikirim oleh Pemerintah Daerah (Pemda) berdasarkan kesepakatan bersama; (2) Dewan Pengawas dapat mewakili penerapan prinsip responsibilitas, hal ini dikarenakan Dewas merupakan salah satu satuan fungsional yang ditunjuk langsung oleh Menteri”.

\section{Independency}

Pada kontek ini, supermasi hukum dimaksudkan bahwa (1) terdapat undang-undang dan peratutan berkaitan dengan dilaksanakannanya pendidikan tingi; (2) terdapat pula sistem reward and punishment yang jelas dampak dari adanya undangundang dan peraturan yang dilaksanakan; (3) system untuk mengawasi dan memantau lembaga penegak hukum diselenggarakan secara independen, obyektif, dan sederhana untuk diakses publik; (4) disosialisasikan peraturan perundangundangan kepada seluruh stakeholder; dan (5) pada pelaksanaan perguruan tinggi, PTN Badan Layanan Umum wajib berpedoman pada ketentuan dan peraturan yang disahkan. Sedangkan Ferry (2010) "penerapan responsibilitas antara lain meliputi: (1); conflict of Interest dapat diartikan sebagai sebuah konflik kepentingan yang terjadi ketika individu atau organisasi yang terlibat dalam berbagai kepentingan yang mungkin bisa merusak motivasi kerja para pegawai (2) larangan aktivitas politik dimaksudkan untuk menjamin kelancaran pelaksanaan tugas, menjaga iklim kerja yang kondusif dan memelihara kondisi kerja serta perilaku yang professional”. 


\section{Fairness}

Prinsip kesetaraan dan kewajaran di Universitas dapat dilakukan dengan menjaga dengan para staf pegawai dan pengajar, yaitu dengan diperlakukannya karyawan sebagai sumber daya yang bernilai melalui sistem knowledge based management sesuai dengan konsep human resource accounting yang mengungkapkan bahwa manusia sebagai sumber daya yang berharga bagi organisasi (Parasmewaran dan Jothi, 2005).

Sedangkan Ferry (2010) penerapan responsibilitas antara lain meliputi: "(1) kesetaraan dan kewajaran antar pegawai yaitu dengan memperlakukan semua pegawai sesuai asas kewajaran dan kesetaraan serta tidak membeda-bedakan antara pegawai satu dengan pegawai lainnya tanpa memperhatikan latar belakang etnis, agama, jenis kelamin, usia, dan cacat tubuh; (2) SPP proporsional bertujuan untuk memberikan kesempatan bagi para mahasiswa yang memiliki ekonomi di bawah ratarata untuk tetap dapat menikmati layanan PT".

Maka, berdasarkan penjelasan di atas, terdapat perbedaan dalam penyelenggaraan good governance pemerintahan yang berlandaskan Instruksi Presiden Nomor 5 Tahun 2004 tentang Percepatan Pemberantasan Korupsi lebih menekankan kepada seluruh aspek, dimulai dari kualitas pelayanan publik hingga melaporkan harta kekayaan bagi penyelenggara negara. Sedagkan untuk keperluan manajemen perguruan tinggi dalam pengendalian anggaran harus ditetapkan unit utama sebagai penanggungjawab program/anggaran yang dipimpin oleh pimpinan unit utama (Dekan/Kepala Biro/Ketua Lembaga/Direktur) yang terdiri dari tiga bagian penting, yaitu: (1) proses perencanaan dan penganggaran; (2) proses pelaksanaan anggaran; serta (3) proses pelaporan dan pertanggungjawaban.

\section{Hambatan Good Coorporate Governance pada Perguruan Tinggi}

Pada dasarnya semua tujuan pasti memiliki hambatan di dalam proses mewujudkannya, begitupun di dalam proses penerapan BLU yang tentunya juga terdapat kendala yang terjadi. Beberapa masalah yang sebenarnya menunjukkan ketidakkonsistenan pemerintah dalam membuat peraturan perundangan yang ditakutkan pada kemudian hari akan menimbulkan kendala. Masalah-masalah ini yang berasal dari internal hingga eksternal dapat dikhawatirkan dapat mengganggu proses kerja BLU secara meyeluruh.

\section{Permasalahan Internal}

Permasalahan yang terjadi pada lingkup internal pendidikan meliputi permasalahan yang berhubungan dengan strategi pembelajaran, peran guru, dan kurikulum. Selain hal tersebut terdapat permasalahan yang lain seperti sistem kelembagaan, profesionalisme guru dan strategi pembelajaran. Permasalahan internal yang pertama adalah sistem lembagaan dengan adanya dualisme atau bahkan dikotomi antar pendidikan umum dan pendidikan agama sebagai permasalahan yang serius karena belum bisa ditemukan solusi hingga sekarang (Ahmad, 2015).

Selain hal tersebut, terdapat permasalahan yang lain, yaitu profesionalisme guru merupakan komponen penting dalam kegiatan pendidikan dan proses pembelajaran adalah pendidik atau guru. Betapapun kemajuan teknologi telah menyediakan berbagai macam alat bantu untuk meningkatkan efektifitas proses pembelajaran, namun posisi guru tidak sepenuhnya dapat tergantikan. Lebih jauh lagi Suyanto (2007) berpendapat bahwa guru yang profesional harus memiliki kualifiakasi dan ciri-ciri tertentu, yaitu: harus memiliki landasan pengetahuan yang kuat, harus berdasarkan atas kompetensi individual, memiliki sistem seleksi dan sertifikasi, ada kerjasama dan kompetisi yang sehat antar sejawat, adanya kesadaran profesional yang tinggi, memiliki prinsip kode etik, memiliki sistem seleksi profesi.

Permasalahan yang terakhir adalah mengenai strategi tenaga pendidik mempunyai pengaruh yang sangat signifikan terhadap pola pembelajaran yang mampu memberdayakan para peserta didik serta pembelajaran yang mampu memberdayakan para peserta didik telah mengubah paradigma pembelajaran dari paradigma pembelajaran tradisional ke paradigma pembelajaran baru (Suyanto, 2007). Maka, berdasarkan pemaparan beberapa ahli dapat disumpulkan terdapat banyak permasalahan yang terjadi di lingkup internal seperti permasalahan yang berhubungan dengan strategi pembelajaran, peran guru, dan kurikulum, strategi tenaga pendidik, adanya kesadaran profesional yang tinggi, memiliki prinsip kode etik serta memiliki sistem seleksi profesi.

\section{Permasalahan Eksternal}

Permasalahan yang terjadi pada lingkup eksternal sesungguhnya sungguh kompleks mencakup dimensi sosial, politik, ekonomi, budaya dan bahkan juga dimensi global. Permasalahan yang pertama yaitu globalisasi penting untuk disoroti karena sangat kuat pengaruhnya pada segenap sektor kehidupan. Di era digital telah terjadi pergeseran paradigma tentang keunggulan suatu negara dari keunggulan komparatif bertumpu pada kekayaan sumber daya alam kepada keunggulan kompetitif bertumbu pada sumber daya manusia yang berkualitas (Kuntowijoyo, 2001).

Sedangkan permasalahan kedua yaitu perubahan sosial merupakan peristiwa yang tidak bisa dielakkan meskipun ada perubahan sosial yang berjalan cepat dan ada pula yang berjalan lambat. Sebagai konsekuensi dari perkembangan ilmu perkembangan dan teknologi yang semikian pesat. Kenyataan menunjukkan bahwa, sebagai konsekuansi dari perkembangan ilmu perkembangan dan teknologi yang demikian pesat, maka perubahan sosial berjalan jauh lebih cepat dibandingkan dengan upaya pembaruan dan laju perubahan pendidikan. Sebagai akibatnya, fungsi pendidikan sebagai konservasi budaya 
menajdiih menonjol, tetapi tidak mampu mengantisipasi perubahan sosial secara akurat (Karim, 1991).

Maka, berdasarkan pendapat dari beberapa ahli dapat disumpulkan terdapat banyak permasalahan yang terjadi di lingkup eksternal seperti globalisasi penting untuk disoroti karena sangat kuat pengaruhnya pada segenap sektor kehidupan, perubahan sosial merupakan peristiwa yang tidak bisa dielakkan

\section{KESIMPULAN}

Sebagaimana tujuan penelitian ini yaitu untuk mengetahui pengertian dari good coorporate governance, penerapan pola pengelolaan good coorporate governance pada perguruan tinggi serta hambatan-hambatan yang dihadapi pada saat pelaksanaan good coorporate governance pada perguruan tinggi. Dan berdasarkan paparan dan pembahasan hasil penelitian yang telah dijelaskan pada bab sebelumnya, maka dapat ditarik kesimpulan sebagai berikut: Good governance memiliki makna sistem tata kelola yang kuat sangat penting untuk memungkinkan lembaga atau organisasi diwujudkan dengan usaha dan semangat kerja oleh semua pihak, yang ditandai dengan adanya prinsip transparansi, akuntabilitas, partisipasi, efisiiensi dan efekktivitas yang sejalan dengan UU No. 12 Tahun 2012 serta fungsi dan peran Tri Dharma PT merupakan kewajiban Perguruan Tinggi untuk menyelenggarakan Pendidikan, penelitian, dan pengabdian kepada masyarakat.

Penerapan pola pengelolaan keuangan BLU terdiri dari tiga bagian penting, yaitu: (1) proses perencanaan dan penganggaran; (2) proses pelaksanaan anggaran; serta (3) proses pelaporan dan pertanggungjawaban. Penerapan prinsip-prinsip dilakukan melalui beberapa penyesuaian berdasarkan nilai-nilai yang wajib dijunjung tinggi dalam pelaksanaan khususnya perguruan tinggi dan pendidikan, terdapat lima prinsip yaitu: (1) prinsip akuntabilitas diwujudkan kompensasi positif berupa insentif kepada para pegawai, kompensasi negatif berupa penjatuhan sanksi atau hukuman; (2) prinsip transparansi dengan melaksanakan pelaksanaan audit eksternal oleh KAP; (3) prinsip pertanggungjawaban dengan upaya yang dilakukan pelaksanaan program kemitraan daerah serta Dewan Pengawas sebagai satuan fungsional Menteri; (4) prinsip kemandirian tanpa adanya pengaruh atau tekanan dari pihak manapun; (5) prinsip kesetaraan dan kewajaran terhadap stakeholders agar setiap stakeholders terlindungi dari upaya penyelewengan baik dalam bentuk usaha untuk kepentingan pribadi maupun benturan kepentingan atau praktik Universitas yang tidak sehat.

Penerapan good governance dalam pengelolaan di Indonesia secara umum belum sepenuhnya memenuhi harapan dan terdapat permasalahan baik dari internal maupun eksternal. Permasalahan internal dapat terjadi dikarenakan sistem lembagaan dengan adanya dualisme, profesionalisme guru dan strategi tenaga pendidik mempunyai pengaruh yang sangat signifikan terhadap pola pembelajaran. Sedangkan permasalahan eksternal yaitu globalisasi, perubahan sosial merupakan peristiwa yang tidak bisa dielakkan meskipun ada perubahan sosial yang berjalan cepat dan ada pula yang berjalan lambat merupakan konsekuansi dari perkembangan ilmu perkembangan dan teknologi yang demikian pesat belum memenuhi kapasitas yang memadai untuk dapat terselenggaranya good governance dalam pengelolaan pendidikan di Indonesia.

\section{REFERENCES}

Anwar, Misbahul., Suryo Pratolo. (2012). Penerapan Model tata Kelola Keuangan Perguruan Tinggi yang Baik untuk Mewujudkan Good University Governance (studi pada PTM se-Indonesia).

Brătianu, Constantin dan Florina Pînzaru. (2015). Challenges for the University Intellectual Capital in the Knowledge Economy. Management Dynamics in the Knowledge Economy Vol.3 no.4, pp. 609-627. ISSN 2392-8042 (online). Faculty of Management (SNSPA).

Darmawati, Deni, Khomsiyah, dan Rika Gelar Rahayu. 2004. Hubungan Corporate Governance dengan Kinerja Perusahaan. SNA VII.391-407.

Direktorat Jenderal Perbendaharaan Kementrian Keuangan. (2013). Manual Pengelolaan Satker BLU Bidang Layanan Pendidikan.

Direktorat Pembinaan PK BLU Direktorat Jenderal Perbendaharaan Departemen Keuangan. (2009). Konsep dan Kebijakan Pengelolaan Keuangan Badan Layanan Umum. (Makalah disampaikan pada Diskusi tentang Pola Pengelolaan Badan Layanan Umum Dalam Rangka Penyusunan Rancangan Undang-Undang Tentang Jaminan Produk Halal di Deputi PerundangUndangan Setjen DPRRI.

Ferry Fambia Anggriawan. (2010). Good Corporate Governance in the Public Service Agency (Case Study at University of Brawijaya Malang).

Hadi, S. (1995). Metodologi Research Jilid 3. Metodologi Research Jilid 3. Yogyakarta. Andi Offset.

H.A.R Tilaar. (2012). Perubahan Sosial dan Pendidikan Pengantar Pedagogik Transformatif untuk Indonesia. Jakarta. Rineka Cipta.

Henard, Fabrice., Mitterle, Alexander. (2010). Governance and Quality Guidlines in Higher Education. OECD.

Higher Education Authority-Irish Universities Association (HEA-IUA). (2007). Governance of Irish UniversitiesA Governance Code of Legislation, Principles, Best Practice and Guidlines. National Development Plan 2007-2013. 
Januri, Fitriani Saragih, Eka Nurmala Sari. (2015). Factors Affecting Good university governance: The Concept of Theoretical. International Journal of Scientific Engineering and Research (IJSER). Index Copernicus Value: 62.86. Impact Factor: 3.791.

John Fielden, (2008). Global Trends in University Governance. Education Working Paper. Series Number 9. The World Bank.

Kaihatu, Thomas S. 2006. Good Corporate Governance dan Penerapannya di Indonesia. Jurnal Manajemen dan Kewirausahaan, Vol. 8, No. 1, Maret 2006: 1-9.

Leni dan Rosmita Rasyid. (2010). Implikasi Penerapan Corporate Governance terhadap Kinerja Perusahaan pada Perusahaan Bank. Jurnal Akuntansi tahun $\mathrm{XIV/januari/2010.}$

Lukman, Mediya. (2013). Badan Layanan Umum, dari Birokrasi Menuju Korporasi. Jakarta. PT Bumi Aksara.

Mantra, Bagoes. Ida. (2008). Filsafat Penelitian \& Metode Penelitian Sosial. Yogyakarta. Pustaka Pelajar.

Meyer, John. W., (2010). World Society, Institutional Theories, and the Actor.Annu. Rev.Sociol. 2010. 36:1-20 First published online as a Review in Advance on February 19, 2010. Department of Sociology, Stanford University, Stanford, California.

Miles, R.E., and Snow, C.C. 1978. Organizational Strategy, Structure, and Process. MCGraw-Hill. New York.

Muchlis R Luddin. (2012). Oligarki Kebijakan Pendidikan, Jakarta: Bina Bangsa Nusantara.

Muhi, A.H. (2010). Implementasi Nilai-nilai Good Governance di Perguruan Tinggi. Sekolah Pascasarjana UPI. Bandung.

Muktiyanto, Ali. (2016). Good University Governance dan Kinerja Program Studi: Pengaruh penerapan akuntansi manajemen, teknik manajemen, dan pilihan prioritas strategi sebagai model mediasi fit. Disertasi. Universitas Indonesia.

Parasmewaran and Jothi (2005). Human Resource Accounting. Department of Commerce,T.S.A.A.S.T College, Perur, Coimbatore, Tamil Nadu.

Peraturan Pemerintah Republik Indonesia Nomor 23 Tahun 2005 Tentang Pengelolaan Keuangan Badan Layanan Umum.

Peraturan Pemerintah Republik Indonesia Nomor 53 Tahun 2010 Tentang Disiplin Pegawai Negeri Sipil.

Peraturan Pemerintah Republik Indonesia Nomor 58 Tahun 2005 Tentang Pengelolaan Keuangan Daerah.

Peters, B. Guy, (2000). Institutional Theory: Problems and Prospects. Department of Political Science, Institute for Advanced Studies (IHS). Stumpergasse 56, A-1060 Vienna.

Quyen, Do Thi Ngoc. (2014). Developing university governance indicators and their weighting system using a modified delphi method. Procedia-Socia and Behavioral Sciences 141, 828-833.

Rhini Fatmasari. (2017). Good university governance, Is It Necessary?. Asian Journal of Education and e-Learning (ISSN: 2321 - 2454). Volume 05- Issue 03, June.

Salmi, J. (2009). The growing accountabilitu agenda in tertiary education: progress or mixed blessing?" Education Working Paper Series N 16. World Bank. Washington, DC.

Sari, Maylina Pramono dan Raharja. (2011). Peran Audit Internal dalam Upaya Mewujudkan Good Corporate overnance pada Badan Layanan Umum (BLU) di Indonesia.

Saur, Timothy D. (2008). The Pursuit of Competitive Advantage and The Strategic Behaviour of Firms in Adopting SelfService Technology. The University of Southern Mississipi, Dissertation. Proquest.

Shattock, Michael. (2006). Managing and Good Governance in Higher Education. Maidenhead, Berkshire: Open University Press.

Soaib, Asimiran (2009). Governance of Public Universities in Malaysia. Unpublished $\mathrm{PhD}$ Thesis, Faculty of Eductaion, University of Malaya.

Surat Keputusan Menteri BUMN No. 117/M-MBU/2002 tanggal 31 Juli 2002 tentang penerapan Good Corporate Governance pada BUMN.

Susi Hambani, Martin Roestamy, dkk. (2015). Akuntabilitas Pengelolaan Pajak Universitas Swasta Melalui Penerapan Prinsip Good- Univerșity Governnance. Jurnal Living Law ISSN 2087-4936 Volume 7 Nomor 1.

Undang-Undang Republik Indonesia Nomor 1 Tahun 2004 Tentang Perbendaharaan Negara.

Undang-Undang Republik Indonesia Nomor 9 Tahun 2009 Tentang Badan Hukum Pendidikan.

Undang-Undang Republik Indonesia Nomor 12 Tahun 2012 Tentang Perguruan tinggi.

Undang-Undang Republik Indonesia Nomor 15 Tahun 2004 Tentang Pemeriksaan Pengelolaan dan Tanggung Jawab Keuangan Negara.

Undang-Undang Republik Indonesia Nomor 17 Tahun 2003 Tentang Keuangan Negara.

Undang-Undang Republik Indonesia Nomor 24 Tahun 2011 Tentang Badan Penyelenggara Jaminan Sosial.

Undang-Undang Republik Indonesia Nomor 25 Tahun 2009 Tentang Pelayanan Publik.

Wijatno, Serian. (2009). Pengelolaan Perguruan Tinggi secara Efisien, Efektif dan Ekonomis untuk Meningkatkan Penyelenggaraan Pendidikan dan Mutu Lulusan. Salemba Empat. Jakarta. 